ISSN 0258-7122

Bangladesh J. Agril. Res. 34(2) : 329-333, June 2009

Short Communication

\title{
INFLUENCE OF NITROGEN ON GRAIN QUALITIES OF FINE RICE GENOTYPES IN AMAN AND BORO SEASONS
}

\author{
M.A.MANNAN ${ }^{1}$, M.S.U.BHUIYA ${ }^{2}$, S.M.A.HOSSAIN ${ }^{3}$ AND M.I.M. AKHAND ${ }^{4}$
}

Key Words: Influence of nitrogen, grain qualities, fine rice, aman and boro.

The grain quality of fine rice genotypes is governed not only by the genotypic make up but also affected by applied nitrogen level. Higher doses of nitrogen sometimes adversely affected on grain quality. Thus, the application of nitrogen would be an optimum level to obtain quality rice. Long slender aromatic rice grain fetches a high price. Elongation of rice grain during cooking is one of the unique features of Basmati rice (Sakila et al., 1999). The quality rice is always preferred by the consumers which contained optimum level of arnylose, expansion of grain lengthwise after cooking and emotion of aroma during cooking (BRRI, 1999). The higher level of protein in rice would mean an increased supply of protein in rice-based diet (BRRI, 2003). Thus, it is important to determine the optimum level of nitrogen and to find out the potential genotypes to obtain higher percentage of protein, aroma, and amylose content.

The experiment was conducted at the Bangladesh Rice Research Institute (BRRI), farm, Gazipur, in Aman and Boro seasons of 2000-01. Nitrogen was applied 0,25, 50, 75, and $100 \mathrm{~kg} \mathrm{~N} / \mathrm{ha}$ in Arnan and 0, 35, 70, 105, and $140 \mathrm{~kg}$ Nha in Boro season. The test Basmati genotypes were Basmati PNR, Basmati 370,Basmati 375, Basmati-D, modem aromatic BR5, BRRI dhan34, BRRI dhan37, RRRI dhan38, and traditional aromatic rice Kalijira, Kataribhog, Chinigura, and Badshabhog. The treatments were distributed in a split plot design placing nitrogen in the main-plots and genotypes in the sub-plots replicated thrice. The soil of the experimental area was clay loam in texture with organic carbon $0.95 \%$, total nitrogen $0.09 \%$, and the soil $\mathrm{pH}$ 6.16. The crop was grown with appropriate management practices in both the seasons. The standard procedures were followed to analyze the grain quality of the test genotypes. The analysis of the grain quality was done as single sample from the composite sample of the three replications of each treatment. The amylose content was determined by tbllowing the procedure as described by Cruz and Khush (2000). Waxy rice $0-2 \%$, very low $3-9 \%$, low $10-19 \%$, intermediate $20-25 \%$, and high $>25 \%$ amylose content. Protein content in rice samples were determined by macro kjeldahl procedures. The aroma was evaluated by following the method suggested by Sood (1978). Single Kernel along with its husk was placed in a vial with capped containing $0.5 \mathrm{~m} 1$ of $1.7 \% \mathrm{KOH}$ solution. After 10 minutes, the cap

\footnotetext{
1 Agronomy Divn. BRRI, Gazipur, ${ }^{2 \& 3}$ Deptt. of Agronomy, BAU, Mymensingh, ${ }^{4}$ Research Fellow, BSMRAU, Gazipur, Bangladesh.
} 
was opened and aroma was inhaled through the nose. Aroma was scored as strong aroma, optimum aroma, and mild level of aroma (DRR, 1998).

Results indicated that the protein content of the grain was affected due to the application of nitrogen (Table 1). The percentage of protein increased with the increase of nitrogen rates. The higher percentage of protein was found in the Boro season. Similar findings were reported by Uppal and Sidhu (1995). Thus, emphasis should be given to apply optimum level of nitrogen to increase protein content in rice because rice is the major source of protein in Bangladeshi diet where it supplies about $50 \%$ of the protein in the diet. The protein content of the test genotypes varied from 7.1 to $10.6 \%$ in brown rice. Basmati PNR contained higher protein followed by Basmati 370 and Chinigura. On the contrary, the lowest percentage of protein was found in Badshabhog. However, BRRI (2002) also found lower protein in Kalijira and Kataribhog and higher protein in modem aromatic rice in Arnan season. However, protein content $<7 \%$ in brown rice was not desirable (BRRI, 2003).

Table 1. Effect of nitrogen on the protein content of fine rice genotypes.

\begin{tabular}{|c|c|c|c|c|c|c|c|c|c|c|}
\hline \multicolumn{11}{|c|}{ Protein content (\%) } \\
\hline \multirow[t]{2}{*}{ Genotypes } & \multicolumn{5}{|c|}{ Aman (2002) } & \multicolumn{5}{|c|}{ Boro (2001) } \\
\hline & $\mathrm{N}_{0}$ & $\mathrm{~N}_{25}$ & $\mathrm{~N}_{50}$ & $\mathrm{~N}_{75}$ & $\mathrm{~N}_{100}$ & $\mathrm{~N}_{0}$ & $\mathrm{~N}_{35}$ & $\mathrm{~N}_{70}$ & $\mathrm{~N}_{105}$ & $N_{140}$ \\
\hline Basmati PNR & 8.4 & 9.1 & 9.3 & 9.8 & 10.5 & 8.4 & 8.8 & 9.1 & 9.7 & 10.6 \\
\hline Basmati 370 & 8.4 & 8.8 & 9.4 & 9.8 & 10.1 & 8.5 & 8.9 & 9.6 & 9.8 & 10.2 \\
\hline Basmati 375 & 7.1 & 7.6 & 8.1 & 8.6 & 8.8 & 7.2 & 7.7 & 8.2 & 8.6 & 8.9 \\
\hline Basmati D & 8.0 & 8.5 & 8.7 & 8.9 & 9.2 & 8.2 & 8.6 & 8.8 & 8.9 & 9.3 \\
\hline Kalijira & 8.0 & 8.4 & 8.6 & 8.7 & 9.1 & 8.2 & 8.5 & 8.7 & 8.8 & 9.2 \\
\hline Kataribhog & 8.0 & 8.4 & 8.6 & 8.9 & 9.2 & 8.1 & 8.4 & 8.7 & 8.9 & 9.3 \\
\hline Chinigura & 8.4 & 8.5 & 8.9 & 9.2 & 9.6 & 8.5 & 8.6 & 8.9 & 9.2 & 9.6 \\
\hline Badshabhog & 7.2 & 7.6 & 7.8 & 8.0 & 8.4 & 7.3 & 7.5 & 7.6 & 8.0 & 8.5 \\
\hline BR5 & 7.8 & 8.3 & 8.6 & 9.0 & 9.2 & 7.9 & 8.3 & 8.5 & 8.7 & 9.4 \\
\hline BRRI dhan34 & 8.0 & 8.2 & 8.6 & 8.9 & 9.2 & 8.2 & 8.4 & 8.7 & 9.0 & 9.3 \\
\hline BRRI dhan37 & 7.8 & 8.0 & 8.3 & 8.6 & 9.1 & 7.9 & 8.1 & 8.5 & 8.8 & 9.2 \\
\hline BRRI dhan38 & 8.0 & 8.2 & 8.6 & 8.9 & 9.4 & 8.1 & 8.3 & 8.6 & 8.9 & 9.5 \\
\hline
\end{tabular}

The amylose content of the test genotypes remained almost stable at different levels of nitrogen (Table 2). Similar trend was also found by Uppal and Sidhu (1995). BRRI (2004) reported that amylose content is a major factor that influences the eating quality of rice. The variation of amylose content of the rice genotypes was 22 to $26 \%$. The Basmati PNR contained higher amylose ( $>25 \%$ ), while the lower amylose was found in Basmati 370, Basmati $375(<24 \%)$. The 
findings of BRRI (2002) had the similarity with this result of this study. However, the intermediate level of amylose in grain (20-25\%) is preferred by the consumers.

Table 2. Effect of nitrogen on the amylose content of fine rice genotypes.

\begin{tabular}{l|c|c|c|c|c|c|c|c|c|c}
\hline \multicolumn{1}{c}{} & \multicolumn{1}{c}{ Amylose content (\%) } \\
\hline \multicolumn{1}{c}{ Genotypes } & \multicolumn{1}{c}{ Aman (2002) } & \multicolumn{5}{c}{ Boro (2001) } \\
\cline { 2 - 12 } & $\mathrm{N}_{0}$ & $\mathrm{~N}_{25}$ & $\mathrm{~N}_{50}$ & $\mathrm{~N}_{75}$ & $\mathrm{~N}_{100}$ & $\mathrm{~N}_{0}$ & $\mathrm{~N}_{35}$ & $\mathrm{~N}_{70}$ & $\mathrm{~N}_{105}$ & $\mathrm{~N}_{140}$ \\
\hline Basmati PNR & 26.0 & 25.0 & 25.0 & 25.7 & 26.5 & 25.6 & 25.0 & 25.8 & 26.0 & 26.5 \\
Basmati 370 & 23.0 & 22.0 & 22.2 & 22.4 & 23.0 & 23.0 & 22.6 & 23.1 & 22.5 & 23.0 \\
Basmati 375 & 22.0 & 23.0 & 22.0 & 23.0 & 22.3 & 22.6 & 23.5 & 23.4 & 24.0 & 23.9 \\
Basmati D & 24.0 & 24.5 & 23.0 & 24.6 & 24.5 & 22.0 & 23.0 & 23.2 & 23.2 & 23.5 \\
Kalijira & 24.4 & 23.8 & 24.3 & 24.0 & 24.2 & 23.6 & 23.4 & 23.5 & 23.0 & 22.9 \\
Kataribhog & 25.5 & 25.6 & 25.0 & 25.8 & 25.3 & 25.5 & 25.6 & 25.8 & 26.0 & 26.1 \\
Chinigura & 25.2 & 25.0 & 25.5 & 25.6 & 25.0 & 25.0 & 25.0 & 24.5 & 25.0 & 25.2 \\
Badshabhog & 24.0 & 24.5 & 24.1 & 24.0 & 24.7 & 23.5 & 24.0 & 24.0 & 24.3 & 24.0 \\
BR5 & 23.5 & 23.4 & 24.0 & 23.5 & 23.6 & 23.5 & 23.8 & 24.0 & 24.0 & 23.5 \\
BRRI dhan34 & 24.7 & 24.0 & 24.6 & 24.5 & 24.2 & 24.4 & 24.3 & 24.4 & 24.3 & 24.6 \\
BRRI dhan37 & 25.1 & 24.5 & 24.6 & 24.2 & 25.0 & 24.5 & 24.3 & 24.6 & 25.1 & 25.0 \\
BRRI dhan38 & 8.0 & 8.2 & 8.6 & 8.9 & 9.4 & 8.1 & 8.3 & 8.6 & 8.9 & 9.5 \\
\hline
\end{tabular}

The aroma content of fine rice slightly varied due to the variation of nitrogen levels. The higher level of aroma was found in Aman season than the Boro crop. Among the test genotypes, the Basmati 370, BR5, BRRIdhan34, BRRIdhan 37 and BRRIdhan 38, Kalijira, and Kataribhog contained higher level of aroma irrespective of nitrogen levels (Table 3). Ai et al. (1993) also found strong aroma in the Basmati 370 in Pakistan. However, BRRI (1999) reported that about $77 \%$ of the people preferred local aromatic rice for better taste. Efferson (1985) stated that aroma is apparently a result of environment as well as genetic factor. Alam (2002) also stated that traditional rice Kalijira showed the higher aroma than modern aromatic rice BR 5. 
Table 3. Effect of nitrogen on the aroma content of fine rice genotypes.

\begin{tabular}{|c|c|c|c|c|c|c|c|c|c|c|}
\hline \multicolumn{11}{|c|}{ Amylose content } \\
\hline \multirow[t]{2}{*}{ Genotypes } & \multicolumn{5}{|c|}{ Aman (2002) } & \multicolumn{5}{|c|}{ Boro (2001) } \\
\hline & $\mathrm{N}_{0}$ & $\mathrm{~N}_{25}$ & $\mathrm{~N}_{50}$ & $\mathrm{~N}_{75}$ & $\mathrm{~N}_{100}$ & $\mathrm{~N}_{0}$ & $\mathrm{~N}_{35}$ & $\mathrm{~N}_{70}$ & $\mathrm{~N}_{105}$ & $\mathrm{~N}_{140}$ \\
\hline Basmati PNR & mild & mild & mild & mild & mild & mild & mild & mild & mild & mild \\
\hline Basmati 370 & strong & strong & strong & strong & strong & strong & strong & moderate & moderate & mild \\
\hline Basmati 375 & moderate & moderate & moderate & moderate & moderate & moderate & mild & mild & mild & mild \\
\hline Basmati-D & moderate & moderate & moderate & moderate & moderate & moderate & mild & mild & mild & mild \\
\hline Kalijira & strong & strong & strong & strong & strong & strong & moderate & moderate & moderate & moderate \\
\hline Kataribhog & strong & strong & strong & strong & strong & strong & strong & strong & moderate & moderate \\
\hline Chinigura & moderate & strong & strong & strong & strong & strong & mild & mild & mild & mild \\
\hline Badshabhog & moderate & moderate & moderate & moderate & moderate & moderate & mild & mild & mild & mild \\
\hline BR5 & strong & strong & strong & strong & strong & strong & moderate & moderate & moderate & moderate \\
\hline BRRIdhan 34 & strong & strong & strong & strong & strong & strong & strong & moderate & moderate & moderate \\
\hline BRRIdhan 37 & strong & strong & strong & strong & strong & strong & moderate & moderate & moderate & moderate \\
\hline BRRIdhan 38 & strong & strong & strong & strong & strong & strong & moderate & moderate & moderate & moderate \\
\hline
\end{tabular}


Thus, the grain quality was assessed in terms of protein, amylose, and aroma contents. The protein increased with the increase of nitrogen levels and higher level of protein was observed in Basniati PNR. The amylose and aroma content of the test varieties did not sharply vary due to the application of nitrogen although aroma was slightly higher at the lower level of $\mathrm{N}$ (below $50 \mathrm{~kg} \mathrm{~N} / \mathrm{ha}$ ). The Basmati 370, BR5, BRRIdhan34, BRRIdhan37, BRRIdhan38, Kalijira, and Kataribhog contained higher level of aroma.

\section{References}

Alam.A.T.M.A. 2002. A study on the performance of some fine rice genotypes in respect of important physicochemical characters. Bangladesh J. Agril. Res. 27(4); 64 1-647.

Ali, S.S., S.J.H. Jafri, M.G. Khan and M.A. Butt. 1993. Inheritance studies for aroma in two aromatic varieties of Pakistan. Intl. Rice Res. News. 18 (2): 6-7.

BRRI (Bangladesh Rice Research Institute). 1999. Annual Report for January 1998-June 1999, Bangkidesh Rice Res. Inst., Gazipur, Pub. no.135. pp.9-35, 243.

BRRI (Bangladesh Rice Research Institute). 2002. Annual Internal Review held on 22-26 December. Soil Sci. Divn, Bangladesh Rice Res. Inst. Gazipur. pp. 3-6, 25-26.

BRR1 (Bangladesh Rice Research Institute). 2003. Annual Internal Review, held on 1923 October. Grain Quality and Nutrition Divn. Bangladesh Rice Res. Inst. Gazipur, pp.2-6.

BRRI (Bangladesh Rice Research Institute). 2004. Annual Internal Review held on 26-29 December, Physiol. Divn, Bangladesh Rice Res. Inst. Gazipur, pp. 23-30.

Cruz, D. and G.S. Khush. 2000. Rice grain quality evaluation procedure. Aromatic Rices. Editors R.K. Singh, U.S. Singh, G.S. Singh. Oxford \& IBH Publishing Co. Pvt. Ltd. New Delhi, pp. 15-28.

DRR (Directorate of Rice Research). 1998. Progress Report. Vol. 1. Varietal Improvement. All India ('oordinated. Rice Improvement Program, Indian Coun. Agril. Res. Rajandrapur, Hyderabad. pp. 10-20.

Efferson, J. N. 1985. Rice quality in world markets. In: Grain Quality and Marketing. Intl. Rice Res. Conf 1-5 June, 1985. Intl. Rice Res. Inst. pp.1-29.

Sakila, M., S. M. Ibrahim, C.R. Anandakumar, S. Backiiyarani and D. Bastian. 1999. Grain quality characteristics of aromatic and non-aromatic rice cultivars. Intl. Rice Res. Notes 24(2): 17-18

Sood, B.C. 1978. Studies on Cooking and Nutritive Quality of Cultivated Rice (Oryza sativa L) with Special Response to Genetics of Kernel Elongation, Aroma and Protein Content. Ph.D. Thesis, Faculty of post-graduate school. Indian Agril. Res. Inst., New Delhi. India, pp. 20-45.

Uppal, S.K. and G.S. Sidhu. 1995. Effect of nitrogen application on milling and physicochernical qualities of rice. Rice India 5(3): 30-33. 